DOI: https://doi.org/10.47405/mjssh.v6i12.1186

\begin{tabular}{|c|c|}
\hline 4.581 & Malaysian Journal of Social Sciences and Humanities (MJSSH) \\
\hline $\begin{array}{l}\text { Malaysian Journa of } \\
\text { socal selenes and }\end{array}$ & Volume 6, Issue 12, December 2021 \\
\hline (MJ-SSH) & e-ISSN : 2504-8562 \\
\hline & $\begin{array}{l}\text { Journal home page: } \\
\text { www.msocialsciences.com }\end{array}$ \\
\hline
\end{tabular}

\title{
The Effects of Infrastructure Investments on Services and Wholesale/Retail Productivity: A Panel-Data Evidence from the Philippines
}

\author{
James Cristofer M. Hermoso'ㅗ Jan Myles M. Sadang1, Nathan Carlo B. Evangelista1, \\ Marie Antoinette L. Rosete ${ }^{1}$ \\ ${ }^{1}$ College of Commerce and Business Administration, University of Santo Tomas, Manila, Philippines \\ Correspondence: Jan Myles M. Sadang (janmyles.sadang.comm@ust.edu.ph)
}

\begin{abstract}
In recent years, infrastructure investments in the Philippines have sharply increased; however, there has been a limited study about whether these have effectively improved productivity, specifically in the Philippines' services and wholesale/retail sectors. This paper examines the effects of investments in roads, bridges, and water supply systems on services and wholesale/retail productivity using the annual dataset from 15 regions in the Philippines from 2017 to 2019. The results of a panel-data analysis with Panel-Corrected Standard Errors (PCSE) show that investments in roads, bridges, and water supply systems positively influence productivity in services and wholesale/retail, with investment for the construction or rehabilitation of roads having the greatest impact.
\end{abstract}

Keywords: infrastructure investment, productivity, services, wholesale, retail

\section{Introduction}

The public infrastructure spending in the Philippines doubled to 6 percent share of GDP in 2017 to 2018 compared to 3 percent in 2011 to 2016 (Department of Budget and Management, 2019). This notable trend is due to the 'Build, Build, Build' (BBB) initiative and other Infrastructure Development Plans (IDPs) as the Philippine government pledges a 'Golden Age of Infrastructure'. Under this objective, the government prioritizes the construction of roads, bridges, and other transport infrastructure that fosters the economic push of the country (Ocampo, 2018). The BBB Program also includes projects that correspond with the target areas of the Philippine Development Plan (Cuenca, 2020).

In the most basic form, infrastructure refers to the fundamental structures or equipment needed for the proper function of a country and the betterment of its economy (O'Sullivan \& Sheffrin, 2003). It provides different commodities that enable, sustain, or enhance living conditions as it covers a lot of sectors like public utilities, public works, transport sector, and structures for healthcare and education, taking up a sizable portion of the economy (Fulmer, 2009; World Bank, 1994). Infrastructure is broadly categorized as economic or social infrastructure. Economic infrastructure refers to facilities that help in the production and distribution within an economy (World Bank, 1994). It improves the marginal utility of other physical infrastructure that allow a more effective exchange of goods and services by enabling producers to access markets (Bottini et al., 2012, as cited in Sabir \& Shamshir, 2020). Meanwhile, social infrastructure raises the marginal productivity of human capital (Bottini et 
al., 2012, as cited in Sabir \& Shamshir, 2020). Examples of social infrastructures are education, health services, and sanitation.

The world is experiencing a significant change with services dominating the share in the world GDP total output, recording a value-added taking up $74 \%$ and $57 \%$ of high-income and low to middleincome countries, respectively (Buckley \& Majumdar, 2018). The Philippines have become more focused on development in international trade and flow of capital, which is caused by the transition of the economy from an agriculture-based to a service-based and manufacturing-based economy (CEIC, 2020). However, despite the significant upward trend of the Philippine service sectors, there are still opportunities to achieve global competitiveness and innovation (Philippine Statistics Authority, 2016). Therefore, the need for sustained growth in the service sectors is often emphasized. For this reason, we aim to examine the impact of infrastructure investments on services and wholesale/retail productivity. We took into account data from 15 regions in the Philippines. This study uses three infrastructure investment variables: road, bridges, and water supply systems, and two economic variables: productivity of services and wholesale/retail.

We aim at contributing to the growing literature by assessing the respective influence of infrastructure investment variables on services and wholesale/retail outputs. We intend to aid the policymakers in infrastructure planning for a more effective realization of targets such as achieving competitiveness and deepening position at the Global Value Chain.

\section{Review of Related Literature}

Investment in infrastructure is a critical component of development as it fulfills community needs with its socio-technical services. Being conceived as society's physical foundation and sunk physical capital, infrastructures provide linkages between technology and the government, capital markets, and nongovernmental intermediaries (Perry, 2001).

Infrastructure has long been cited as instrumental to a country's economic growth and development. Development Economists have been consistent with their findings on the significant positive macroeconomic and microeconomic impacts of viable infrastructures.

Bivens (2017) highlighted that investment in infrastructure could be a factor in gaining stability within an economy, in the macroeconomic level, because most estimation output for infrastructure spending is significantly better than other interventions, which means that it is more significantly efficient than any other tax cuts, and shows that an increase in spending in infrastructure will stimulate business growth and, ultimately, the economy itself.

According to Stupak (2018), infrastructure is a factor that makes it possible to produce products with more efficiency, which the government takes into account, with the assumption that it will increase economic output by stimulating demand and increasing productivity. These changes affect the level of employment in the economy. When infrastructure spending increases, there is a significant decrease in unemployment; however, this effect is noticeably based upon the situation that the economy is facing.

Hontley (2021) also concluded that an increase in public capital like infrastructure increases the productivity of private capital and labor productivity. Such phenomena cause an increase and decrease in wage rate and borrowing interest rate, respectively, leading to more working and investing motivation. Ultimately, these factors increase Gross Domestic Product, and due to this, government revenue from income taxes increases while debt and deficit decrease.

\section{Infrastructure Investment on Services Productivity}

Black (2014) concluded that capital investments turned toward transportation development trigger economic activity that produces long-term benefits due to the resulting accessibility to jobs, services, and even markets. Meanwhile, Nilsson and Smirnov (2016) found that access to transportation 
infrastructure creates competition, making competing firms locate near each other, affecting economic outcomes, travel demand distribution, and accessibility for consumers. Holl (2016) also estimated that the accessibility and existence of highways increase economic activity and productivity at the firm level.

Transportation infrastructure expansion affects market potential in Spain by measuring travel time through transport line networks and taking into account the developments in transportation. The results found out that improvement in infrastructures like roads positively impacts market potential, precisely firm productivity, because of the increased accessibility to resource and consumer market, which results in economic growth (Holl, 2012; Pradhan \& Bagchi, 2013). Using both primary and secondary data run through Probit and Multivariate models, respectively, which were used to analyze the longterm effect of road infrastructure on the growth of Nigeria, results showed that transport infrastructure positively and significantly affects growth in the economy which means economic growth is dependent on the level of accessibility and quality of road developments (Siyan et al., 2015).

An analysis done by $\mathrm{Ng}$ et al. (2019) regarding the impact of socio-economic factors and development of road infrastructure on the economic growth, which utilized cross-sectional time series data that were run through fixed-effect panel linear regression, showed that road developments and socio-economic have a positive effect on the growth of the economy. Moreover, Arbués et al. (2015) concluded by applying Maximum Likelihood and Generalized Moments estimators that road infrastructure positively affects the economic output in both the region where the infrastructure is and even the provincial neighbors have access to the road.

Bridges, meanwhile, also play a significant role in promoting urban agglomeration. Chu et al. (2021) concluded that bridges hasten urban-rural sprawl. Through Interrupted Time Series Analysis (ITSA), they analyzed the socio-economic impacts of the Hangzhou Bay Bridge construction. In which, they found that it rapidly increased tourism, industry, and GDP. These findings are consistent with the conclusions of Gautam (2020), which suggest that as the bridge connects the local people, there is an improvement in the transportation system. As a result, it facilitates more accessible access to services and promotes rural development. Agglomeration increases business activities and stimulates demand for services, thereby also positively influencing productivity.

Bridges also reduce costs. As evidenced by Aktan and Attanayake (2015), bridges improve mobility and reduce traffic, lifestyle, and user costs. The reduction of costs has a positive and significant influence on nearby businesses and communities. Ibok and Daniel (2013) add that decreasing the expenses increases production output and expands the exchange of services. In turn, benefits on agriculture, industrialization, and employment are also realized.

Meanwhile, since a broad spectrum of industries is most reliant on water and wastewater utilities, having access to dependable, clean, and reasonably priced water and wastewater services helps businesses generate goods and services (AECOM, 2014). It is consistent with the findings of Cosgrove and Loucks (2015), wherein they concluded that inadequate clean water for human consumption and sanitation is a constraint on productivity. Investments in water supply systems play a vital role in employment generation, human health, economic growth, and global competitiveness. Water infrastructure and other public goods generate direct, indirect, and induced jobs throughout the economy (Gordon et al., 2011).

Hypothesis 1: Infrastructure Investment on Roads, Bridges, and Water Supply Systems increase Services Productivity

\section{Infrastructure Investment on Wholesale/Retail Productivity}

According to Draper (2014), wholesale is an industry that sells finished or final goods to retailers, merchandising businesses, and commercial users, while retail is an organized seller of products in smaller quantities to public consumers. These industries are part of the distributive trades sector, 
which serves as the bridge to distribute products and goods between producers and consumers and takes up a significant level in the output and employment within the economy.

Being a retailer, according to Sullivan (2016), means that a person has control over how much, when, and where the small quantities of product are sold and have the ability to have a real-time interaction with customers, which makes it possible for quicker incorporation of new designs based on feedback on products. On the flip side, wholesalers can sell large amounts of products at once and distribute them to consumers through multiple venues, opening up more possible paths for revenue, which gives the business stability.

Transportation systems like roads and bridges have productivity effects on businesses and firms through production cost reduction, agglomeration of businesses, increased demand and output, and lower distribution cost, which causes ripple or domino effects in the economy, kick-starting the earning of revenue and the possibility of business expansion and increase in economic activity and land value in the local level (Black, 2012). An empirical exploratory study by Yu et al. (2012) using provincial and municipal panel data from 1978 to 2008 showed that investment in transportation infrastructure in central region Chinese provinces, especially on the bridge connecting the eastern and western side, have a positive and significant effect on economic returns because of the increased accessibility of the western market which is known to be less developed.

In the study by Jiménez and Perdiguero (2011), they concluded that better quality roads resulted in more productivity for the retail markets. In another study by Etemadnia et al. (2013), they conducted different experiments to determine a better efficiency solution to the wholesale market by different network costs, including transportation, distance, capital, and importantly road conditions. The results showed that most of the variables, especially road conditions, increase efficiency for wholesale markets. In the study by Slamet et al. (2017), they conducted an experiment to see how small-scale farmers participating in the modern retail market affect their income and its determinants. They found a similarity between higher education levels, irrigated land, facilities, and better road infrastructure, specifically paved roads. With these common variables, they concluded that by having these in mind, other small-scale farmers could also boost their income and participate in modern retail markets.

A study done by De Borger et al. (2019) utilized a two-step estimation approach to analyze the effect of the opening of the Great Belt Bridge, which connects Copenhagen with the mainland of Denmark, on the firm productivity within the country showed that improved accessibility given by the bridge positively impacts the productivity of firms that venture in the industry of construction and retail. A study utilizing panel data run through the Difference-in-Difference approach showed that Bridge construction caused a reduction in transport and trade cost due to increased connectivity and accessibility of market areas which led to the revival of the economy through improvements in factors like resource allocation and efficiency in production caused by increased competition (Blankespoor et al., 2018).

Water supply systems are types of infrastructure that provide water supply, whether for human consumption, power, or ecosystem. In the research by Davis et al. (2001), through empirical evidence in Uganda, they found that water supply systems impact microenterprises, including wholesale and retail, although the economic benefits are limited. They added that the significant economic impact of water supply systems to wholesale and retail are mostly realized in markets that deal with agriculture, such as fishing. In the research by Hellin et al. (2009) on understanding markets in Meso-America, the results showed that though water supply systems and a minimal economic impact on markets, it is mostly realized by agriculturally-based organizations/markets as these types of markets can fully utilize the water supply systems implemented in their area. In the paper of Okello et al. (2007), it was concluded infrastructure is significant, like water supply systems, to the earnings made by the farmers. Since the water infrastructure is poor in their area, they would either not be able to meet standard buyer requirements, which will be compiled with the additional transactional costs from the producer side, hence water supply systems being a significant variable in the productivity of farmers' wholesale and retail markets in Africa. 
Hypothesis 2: Infrastructure Investment on Roads, Bridges, and Water Supply Systems increase Wholesale/Retail Productivity

\section{Method}

\section{Study Design}

We conducted quantitative research through panel data analysis to assess the impacts of infrastructure investments on services and wholesale/retail productivity. We have identified the independent variables, the amount allocated to construction or rehabilitation of roads, bridges, water supply systems, and the dependent variables, Gross Value Added in Services and Wholesale/Retail. Figure 1 depicts the linkages between these variables.

Figure 1. Simple Analytical Framework depicting the relationship between Infrastructure Investment and Gross Value Added in Services and Wholesale/Retail

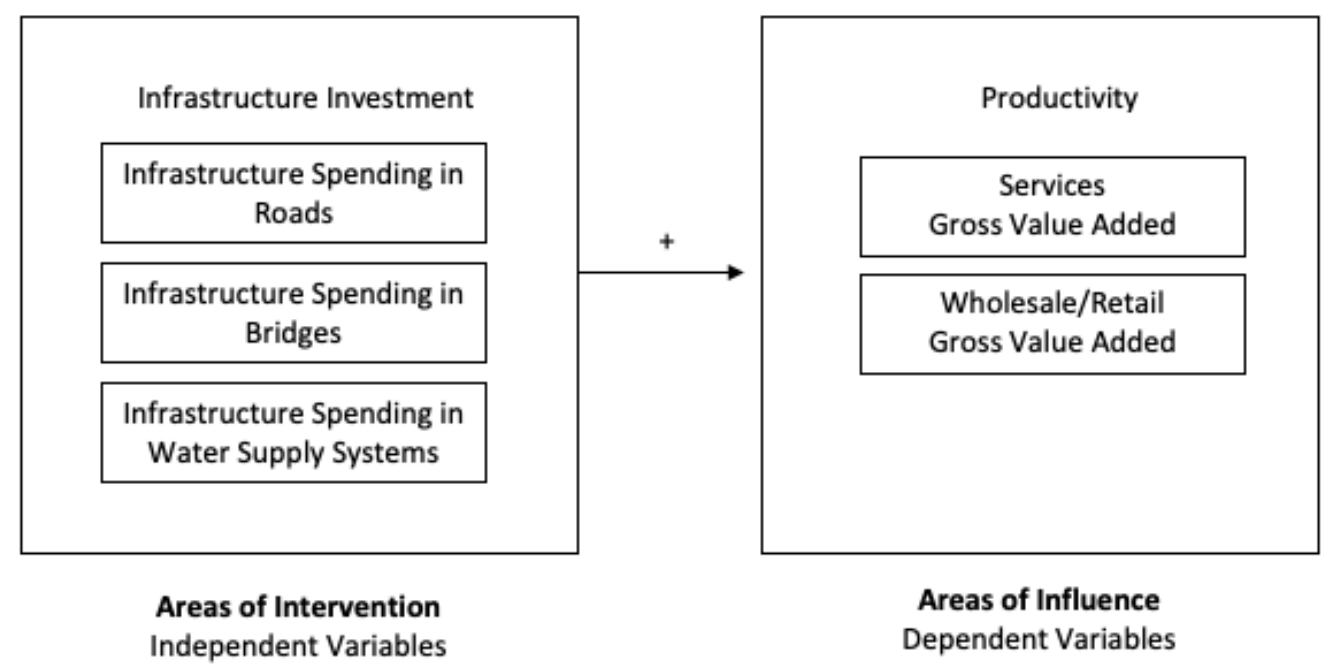

\section{Panel Data Analysis}

Panel data refers to the pooling of variables with time and cross-sections dimensions (Baltagi, 2005). Using panel data has many advantages. They are more suited to analyzing dynamics of change because they investigate repeated cross-section observations and allow exploring more complex behavioral models (Gujarati \& Porter, 2008). However, despite these, panel data offer several estimate and inference challenges. Other issues to consider are heteroscedasticity, autocorrelation, and crosscorrelation that plague cross-sectional and time-series data (Gujarati \& Porter, 2008).

The data is a combined 45 observations from 15 regions in the Philippines, on a three-year frame from 2017-2019. The following models are used in meeting the objectives of the study:

\section{Model 1 (WholesaleRetail):}

WholesaleRetail $=\beta 0+\beta 1$ (Roads) $+\beta 2$ (Bridges) $+\beta 3$ (WaterSupplySystems) $+\alpha i t$

\section{Model 2 (Services):}

Services $=\beta 0+\beta 1$ (Roads) $+\beta 2($ Bridges $)+\beta 3$ (WaterSupplySystems $)+\alpha i t$

Model 1 tests the relationship between Wholesale and Retail and Infrastructure Spending on Roads, Bridges, and Water Supply Systems. On the other hand, Model 2 tests the relationship between Services and Infrastructure Spending on Roads, Bridges, and Water Supply Systems. 


\section{Descriptive Statistics}

Table 1 presents the descriptive results for the variables used in our model. The data for the independent variables were obtained from the Philippines Statistics Authority, while the data used for the dependent variables were obtained from the Department of Budget and Management. lnRoads is the amount appropriated for construction and rehabilitation of local roads under the local infrastructure program in logarithmic form. InBridges is the amount appropriated for construction and rehabilitation of local bridges under the local infrastructure program in logarithmic form. $\ln W$ aterSupplySystems is the amount appropriated for construction and rehabilitation of water supply systems under the local infrastructure program in logarithmic form. Meanwhile, lnWholesaleRetail is the Gross Value Added in Wholesale and Retail in logarithmic form, and lnServices is the Gross Value Added in Services in logarithmic form.

Table 1: Descriptive Statistics of Dependent Variables and their Determinants

\begin{tabular}{llll}
\hline Independent Variables & Units & Mean & SD \\
\hline lnRoads & in thousand Pesos & 13.23245 & 0.669722 \\
lnBridges & in thousand Pesos & 10.15206 & 1.248609 \\
lnWaterSupplySystems & in thousand Pesos & 10.35511 & 0.9548618 \\
Dependent Variables & & & \\
lnWholesaleRetail & $\begin{array}{l}\text { in thousand Pesos, current } \\
\text { Price }\end{array}$ & 18.37419 & 0.7573796 \\
$\ln$ in thousand Pesos, current & 19.5899 & 0.6727313 \\
\hline
\end{tabular}

\section{Testing for Multicollinearity}

Table 2 is the test for multicollinearity, in which the test for Variance Inflation Factor (VIF) was used. VIF is utilized to understand the viewable increasing speed of variances and covariances and can also show how much inflation a variance of an estimator has due to multicollinearity (Gujarati \& Porter, 2008). Research variables should have a correlation with one another. However, problems would arise in the research when there is a high correlation between independent variables. If there is such a case among the variables, it will cause inflations on the regression results, which is referred to as multicollinearity (Pallant, 2007). To understand whether the variables do have evidence of a multicollinearity problem, the VIF model is used. When values of VIF are greater than 10 or the tolerance level is less than 0.10 , there is evidence of multicollinearity problems within the model (Hair et al., 2006).

Table 2: VIF Coefficients and Tolerance Level of Independent Variables

\begin{tabular}{lll}
\hline Variable Name & VIF & $\mathbf{1 / V I F}$ \\
\hline lnRoads & 1.57 & 0.635212 \\
lnBridges & 1.73 & 0.577575 \\
lnWaterSupplySystems & 1.14 & 0.875056 \\
Mean VIF & 1.48 & \\
\hline
\end{tabular}


DOI: https://doi.org/10.47405/mjssh.v6i12.1186

As shown in Table 2, we can see that no variable has reached the threshold of greater than $10 \mathrm{VIF}$, and no variable has gone below the threshold of 1/VIF (Tolerance) of less than 0.10 . Thus the independent variables show no evidence of the multicollinearity problem.

\section{Hausman Specification Test}

The Hausman Specification Test determines if the Fixed Effect or the Random Effect is the more appropriate model. The null hypothesis underlying the Hausman test indicates such since Fixed Effect Model and Random Effect Model do not differ substantially (Gujarati \& Porter, 2008). If the null hypothesis is less than 0.05, then the Fixed Effect Model is more appropriate than the Random Effect Model. In Tables 3, the results for model 1 and model 2, are 0.0079 and 0.0075 , respectively. Hence, Fixed Effect is preferred and is employed for this study.

Table 3: Hausman Specification Test Results

\begin{tabular}{lll}
\hline Models & Chi-Square Statistic & P-value \\
\hline Model 1 (lnWholesaleRetail) & 11.84 & 0.0079 \\
Model 2 (lnServices) & 11.97 & 0.0075 \\
\hline
\end{tabular}

\section{Fixed Effects Estimation}

Fixed Effects Estimation is used when fixed factors constantly occur over certain variables (Chen, 2021). It is a model that makes it possible to lessen the possibility of variable bias caused by timeinvariant unobservable variables (Dranove, 2009). It is utilized in a panel data setting with nonmeasurable and unchanging variables that correlate with the observed independent variables and, in some cases, can have a certain level of effect on the dependent variables (Farkas, 2005).

Table 4 shows the Fixed Effects Estimation results regarding the relationship of lnWholesaleRetail and lnServices with the three independent variables, namely, lnRoads, lnBridges, and lnWaterSupplySystems. Model 1 and 2 results show that only lnRoads have a significant and positive relationship with Gross Value Added in Wholesale/Retail and Services. Meanwhile, lnBridges and lnWaterSupplySystems have insignificant and positive relationships with Gross Value Added in Wholesale/Retail and Services.

Table 4: Fixed Effects Estimation and Diagnostic Tests Results

\begin{tabular}{lllll}
\hline Dependent Variables & \multicolumn{2}{l}{$\begin{array}{l}\text { Model 1 } \\
\text { (lnWholesaleRetail) }\end{array}$} & \multicolumn{2}{l}{ Model 2 (InServices) } \\
& Coefficient & P-value & Coefficient & P-value \\
\hline lnRoads & 0.0942643 & 0.050 & 0.1021945 & 0.029 \\
lnBridges & 0.0235184 & 0.206 & 0.025697 & 0.154 \\
lnWaterSupplySystems & 0.039184 & 0.134 & 0.034036 & 0.176 \\
C & 16.48232 & 0.000 & 17.62429 & 0.000 \\
R-square & 0.4391 & & 0.4681 & \\
Diagnostic Tests & & & & \\
Modified Wald Test for & $9.08 \mathrm{E}-79$ & & 0.0000 & \\
\hline
\end{tabular}


Groupwise Heteroscedasticity

\begin{tabular}{lcc}
$\begin{array}{l}\text { Wooldridge Test for } \\
\text { Autocorrelation }\end{array}$ & $9.86 \mathrm{E}-07$ & $6.63 \mathrm{E}-08$ \\
$\begin{array}{l}\text { Pesaran Cross-Sectional } \\
\text { Dependence Test }\end{array}$ & $1.62 \mathrm{E}-23$ & $3.60 \mathrm{E}-21$ \\
\hline
\end{tabular}

However, diagnostic tests are employed to test for the consistency and efficiency of these Fixed Effects Estimation results. There are some instances that some models have autocorrelation and heteroscedasticity, which cause standard error biases and lower efficiency. There is also the likelihood of cross-sectional dependence, which causes the instances of shocks and unobservable components that can cause errors (Freire-Seoane et al., 2020).

\section{Testing for Heteroscedasticity and Autocorrelation}

Heteroscedasticity might be present in panel data where the cross-sectional units may be of different sizes and hence exhibit inconstant variances across observations (Baltagi, 2005). As a result, OLS estimators become inefficient even with large sample sizes. Although the unbiasedness and consistency are not destroyed, the standard hypothesis-testing process becomes dubious (Gujarati \& Porter, 2008). Hence, testing for heteroscedasticity is necessary for panel data.

Modified Wald test detects Groupwise heteroskedasticity in a fixed-effects model (Baum, 2001; Greene, 2002). The null hypothesis is homoscedasticity. Findings from the table show that the null hypothesis is rejected for models 1 and 2 at 5\% significance level. Hence, heteroscedasticity in both models is concluded.

Since panel data have time-series dimensions, autocorrelation is a possibility. Autocorrelation has the same effects as heteroskedasticity: OLS stays unbiased, but it becomes inefficient, and its standard errors are computed incorrectly (Gujarati \& Porter, 2008; Verbeek, 2004).

While various tests for autocorrelation in panel-data models are available, Wooldridge (2002) proposes a method that requires few assumptions and is simple to execute using the residuals from a first-differences regression (Drukker, 2003). The null hypothesis is no first-order autocorrelation. Findings from Table 4 show that autocorrelation is present in both models, as the null hypothesis is rejected at $5 \%$ significance level.

\section{Testing for Cross-Sectional Dependence}

Cross-sectional dependence, in which all units in the same cross-section are correlated, can be found in panel data (Henningsen \& Henningsen, 2019). It can be due to some unobserved common shocks that are shared by all units and affect them all, albeit in different ways (Henningsen \& Henningsen, 2019; De Hoyos \& Sarafidis, 2006). Hence, we cannot ignore cross-sectional dependence, resulting in biased test results or contemporaneous correlation (Hoechle, 2007).

Since our model has a short time and cross-sections dimensions, it is most fitting to use the Pesaran test for Cross-Sectional Dependence as it is centered correctly for fixed N and T (Tugcu, 2018; Pesaran, 2004). Pesaran Cross-Sectional Dependence tests the correlation of residuals across entities with the null hypothesis of no cross-sectional dependence (Torres-Reyna, 2018). Findings from Table 4 show that cross-sectional dependence exists for models 1 and 2 with the rejection of null hypothesis at $5 \%$ significance level.

The Hausman Specification test concluded that the more appropriate model is the fixed effect model. However, the presence of cross-sectional dependence in a panel data analysis discourages the use of Fixed Effects and Random Effects estimators due to inefficiency in estimate and potential bias in standard error estimation (Nayeripour \& Kheshti, 2011; Reed \& Ye, 2009). 


\section{Panel-Corrected Standard Error}

In studies that use panel data, there are different varieties of possible estimators to utilize that are robust to heteroscedasticity, autocorrelation, and serial dependence such as the Feasible Generalized Least Squares (FGLS) and the Panel-Corrected Standard Errors (PCSE) (Reed \& Webb, 2010; Bailey \& Katz, 2011). FGLS is one of the most relevant estimators to use for applied research, but it certainly has some limitations like it cannot appropriately estimate when the number of periods $(\mathrm{T})$ is less than the number of cross-sections (N) (Moundigbaye et al., 2017). In a simulation study done by Beck and Katz (1995), it was shown that Feasible Generalized Least Squares (FGLS) or Parks model generates significantly low confidence intervals within the estimated standard errors, which often underestimates the variability of the data. With this in mind, they suggested that for estimating time-series crosssection data, Ordinary Least Square coupled with a covariance estimator known as Panels Corrected Standard Errors (OLS-PCSE) can be utilized.

PCSE is defined as a type of estimator for OLS estimator variance-covariance matrix and is usually used when the data has many observations and a few panels (StataCorp, 2013). PCSE is more likely to be used when $\mathrm{T}<\mathrm{N}$ to prevent underestimating cross-sectional correlation (Miao et al., 2019). More so, Panel-Corrected Standard Errors (PCSE) provide dramatic result improvements more than FGLS in the realm of standard errors estimation (Reed \& Webb, 2010). A Monte-Carlo experimental analysis shows that even though FGLS has good efficiency properties, it is limited by the poor level of estimated standard errors, while PCSE produced standard errors and test results that were superior and more accurate for hypothesis testing (Moundigbaye et al., 2019).

\section{Results}

Table 5 shows the Panel-Data Analysis with PCSE Estimation results regarding the relationship between $\ln$ WholesaleRetail and $\operatorname{lnServices}$ with the three independent variables, namely, lnRoads, lnBridges, and lnWaterSupplySystems.

The results from Model 1 show that all independent variables have a significant and positive relationship with Gross Value Added in Wholesale/Retail. Investments on the construction or rehabilitation of roads have the highest impact on wholesale/retail productivity. For every unit increase in lnRoads, there is 0.2803 increase in lnWholesaleRetail, assuming ceteris paribus. Meanwhile, every unit increase in lnWaterSupplySytems and lnBridges boosts lnWholesaleRetail by 0.2101 and 0.1208 , respectively, assuming ceteris paribus.

Table 5: Panel Data Analysis with Panel-Correct Standard Error Results

\begin{tabular}{lllll}
\hline Dependent Variables & \multicolumn{2}{l}{ Model 1 (InWholesaleRetail) } & \multicolumn{2}{c}{ Model 2 (InServices) } \\
& Coefficient & P-value & Coefficient & P-value \\
\hline lnRoads & 0.2803641 & 0.014 & 0.3207602 & 0.001 \\
lnBridges & 0.1208959 & 0.009 & 0.0757266 & 0.033 \\
lnWaterSupplySystems & 0.2101484 & 0.012 & 0.1862377 & 0.015 \\
C & 0.0942643 & 0.000 & 12.5257 & 0.000 \\
R-square & 0.9955 & & 0.9976 &
\end{tabular}

On the other hand, Model 2 shows that all independent variables have a significant and positive relationship with Gross Value Added in Services. Investments on the construction or rehabilitation of 
roads also have the highest impact on services productivity. For every unit increase in lnRoads, there is 0.3207 increase in lnServices, higher than its effect on lnWholesaleRetail, assuming ceteris paribus. Meanwhile, every unit increase in lnWaterSupplySytems and lnBridges boosts $\ln$ WholesaleRetail by 0.1862 and 0.0757 , respectively, assuming ceteris paribus.

\section{Discussion}

The study ascertained the positive relationship between services and wholesale/retail productivity and infrastructure investment on roads, bridges, and water supply systems. It also concluded that the construction or rehabilitation of roads has the greatest impact on both sectors, followed by the construction or rehabilitation of water supply systems and bridges, respectively.

The significance of variables supported the hypotheses and are in line with the earlier studies. Roads, bridges, and water supply infrastructure investments boost services and wholesale/retail outputs. Transport infrastructure provides long-term benefits and triggers economic growth by improving the accessibility of consumers and producers to markets, jobs, and services (Black, 2014). As a result, it encourages agglomeration, promotes competition and innovation, and increases productivity at the firm level (Nilsson \& Smirnov, 2016; Holl, 2016). Meanwhile, because water is a fundamental input in various industries, having access to dependable, clean, and reasonably priced water services allows businesses to produce more goods and services (AECOM, 2014). Furthermore, it has ripple effects that induce employment and economic growth, similar to other physical infrastructures (Gordon et al., 2011).

Despite the Philippines' growth in the services industry, there are still opportunities to strengthen the country's global competitiveness. Such outcomes are unrealized due to a lack of infrastructure and other public goods investments, as well as an unsuitable business environment (Mitra, 2013). Infrastructure has a cascading impact, facilitating trade and economic streams. They directly affect businesses by lowering input costs and operating expenses, consequently allowing them to trade more efficiently and competitively at the national and global levels.

The study found the effectiveness of infrastructure investments as an intervention in stimulating the country's services and wholesale/retail productivity. Hence, in sustaining the growth of these sectors, there is a need to accelerate infrastructure spending. Productivity dictates the flow of an economy. The increase in productivity in services and the wholesale/retail sector through the strengthening of competitive edges and innovation allows an economy to capture the benefits of trading opportunities and supply chains, which positively spills over to the individuals through the improvement of jobs and living conditions.

\section{Implications}

This research has strong theoretical implications as it contributes to the limited literature between infrastructure investments and productivity in the Philippine context. As the Philippine government plans to continuously increase infrastructure spending, this research aids in evaluating their effectiveness at realizing the development goals, specifically for the services and wholesale/retail sectors. Since there is a significant and positive relationship between the infrastructure and economic variables, we implore the importance of boosting the country's infrastructure spending through adequate investment and development policies. They induce ripple effects that ultimately benefit businesses and individuals in society.

\section{Conclusion}

Infrastructure remains central in the growth and development of a country. It has microeconomic and macroeconomic benefits that are realized in the short run and in the long run. This study underscores 
the importance of infrastructure investment on the productivity of services and the wholesale/retail industry. It promotes market access, decreases barriers, and allows innovation, which enable these sectors to also position in global production and trade.

With only one of the many pieces to fully understand, future research can consider other physical infrastructures, such as flood control, telecommunications, power supply systems, and other social infrastructures, such as hospitals, schools, and housing programs. Further study can also establish whether the quality of infrastructure has a significant impact on the productivity of services and wholesale/retail sectors.

\section{References}

AECOM. (2014). National Economic and Labor Impacts of the Water Utility Sector. Water Research Foundation and Water Environment Research Foundation. Retrieved from http://cdcauthority.org/WERF\%20Economic\%20Impact\%20Full\%20Report.pdf

Aktan, H., \& Attanayake, U. (2015). Research on Evaluation and Standardization of Accelerated Bridge Construction Techniques, Michigan Department of Transportation, Lansing, MI, 2015. Retrieved from https://www.michigan.gov/documents/mdot/Evaluation_and_Standarzitation_of_ABC_Techniq ues-Final_Report-09-21-2017-Part_II_606393_7.pdf

Arbués, P., Baños, J., \& Mayor, M. (2015). The spatial productivity of transportation infrastructure. Transportation Research Part A: Policy and Practice, 75, 166-177.doi:10.1016/j.tra.2015.03.010

Australia Bureau of Statistics. (2019). Wholesale trade and Retail trade industries: a comparison. Retrieved from https://www.abs.gov.au/articles/wholesale-trade-and-retail-trade-industriescomparison

Bailey, D., \& Katz, J. N. (2011). Implementing panel corrected standard errors in R: The PCSE package. Retrieved from https://cran.r-project.org/web/packages/pcse/vignettes/pcse.pdf

Baltagi, B.H. (2005). Econometric Analysis of Panel Data. 3rd Edition, John Wiley \& Sons Inc., New York.

Baum, C. (2001). Residual diagnostics for cross-section time series regression models. Stata Journal, $1,(1), 101-104$.

Beck, N., \& Katz, J. N. (1995). What to do (and not to do) with time-series cross-section data. Retrieved from https://authors.library.caltech.edu/44319/1/beck\%2Bkatz95.pdf

Bivens, J. (2017). The potential macroeconomic benefits from increasing infrastructure investment/ Economic Policy Institute. Retrieved from https://www.epi.org/publication/the-potentialmacroeconomic-benefits-from-increasing-infrastructure-investment/

Black, A. (2012). Facilitating Economic Growth: The Impact of a $\$ 600$ Million Increase in Minnesota's Annual Highway \& Bridge Capital Outlays. Retrieved from https://www.transportationalliance.com/sites/ta/files/uploads/documents/basic-pages/202006/Minnesota-report\%20\%283\%29.pdf

Black, A. (2014). The Economic Impact of Highway \& Bridge Construction Investment in Virginia. Retrieved from https://vbtva.com/resources/docs/artba_virginia_report_final.pdf

Blankespoor, B., Emran, S., Shilpi, F., \& Xu, L. (2018). Bridge to bigpush or backwash? Market integration, reallocation and productivity effects of Jamuna Bridge in Bangladesh. Retrieved from

https://openknowledge.worldbank.org/bitstream/handle/10986/29981/WPS8508.pdf?sequence= 1\&isAllowed $=$

Bottini, N., Coelho, M., Kao, J., (2012). Infrastructure and growth. London School of Economics. Retrieved from http://www.lse.ac.uk/resea rchAndExpertise/units/growthCommission/documents/pdf/SecretariatPapers/Infrastructure.pdf

Buckley, P., \& Majumdar, R. (2018). The services powerhouse: Increasingly vital to world economic growth. Retrieved from https://www2.deloitte.com/us/en/insights/economy/issues-by-thenumbers/trade-in-services-economy-growth.html 
CEIC. (2020). Philippines' economy and the effects of industrial and urbanisation. Retrieved from https://info.ceicdata.com/philippines-economy-and-the-effects-of-industrial-and-urbanisation

Chen, L. (2021). Fixed Effect Regression - Simply Explained. Retrieved from https://towardsdatascience.com/fixed-effect-regression-simply-explained-ab690bd885cf

Chu, L., Zou, Y., Masiliūnas, D., Blaschke, T., \& Verbesselt, J. (2021). Assessing the impact of bridge construction on the land use/cover and socio-economic indicator time series: A case study of $\begin{array}{llll}\text { Hangzhou } & \text { Bay } & \text { Bridge. } & \text { Retrieved }\end{array}$ https://www.tandfonline.com/doi/full/10.1080/15481603.2020.1868212

Cosgrove, W. J., \& Loucks, D. P. (2015). Water management: Current and future challenges and Research Directions. Water Resources Research, 51(6), 4823-4839. https://doi.org/10.1002/2014wr016869

Cuenca, J. (2020). Review of the "Build, Build, Build" Program: Implications on the Philippine Development Plan 2017-2022. Discussion Papers DP 2020-54, Philippine Institute for Development Studies. Retrieved from https://pidswebs.pids.gov.ph/CDN/PUBLICATIONS/pidsdps2054.pdf

Davis, J., Kang A., Vincent J., \& Whittington, D. (2001). How Important is Improved Water Infrastructure to Microenterprises? Evidence from Uganda, 29(10), 1753-1767. doi:10.1016/s0305-750x(01)00059-6

De Borger, B., Mulalic, I., \& Rouwendal, J. (2019). Productivity Effects of an Exogenous Improvement in Transport Infrastructure: Accessibility and the Great Belt Bridge. Tinbergen Institute. Tinbergen Institute Discussion Papers No. TI 2019-065/VIII. Retrieved from https://papers.tinbergen.nl/19065.pdf

De Hoyos, R., \& Sarafidis, V. (2006). Testing for cross-sectional dependence in panel-data models, Stata Journal, 6, issue 4, p. 482-496.

Department of Budget and Management. (2019). Infrastructure Outlays to GDP ratio twice the deficit to GDP ratio. Retrieved from https://www.dbm.gov.ph/index.php/secretary-s-corner/pressreleases/list-of-press-releases/1385-infrastructure-outlays-to-gdp-ratio-twice-the-deficit-to-gdpratio?fbclid=IwAR2vX7akVv-gianuE5cblOaLCd1PAL3BIDfQvlI0bRFOBaKP1Hju3O6fFDo

Dranove, D. (2009). Spring 2009 Mgmt 469, Empirical Methods in Strategy: Fixed Effects Models. Retrieved

from https://www.kellogg.northwestern.edu/faculty/dranove/htm/dranove/coursepages/Mgmt\%20469 /Fixed\%20Effects\%20Models.pdf

Draper, C. (2014). Wholesale and retail trade services: Industry description. Retrieved from https://www.oecd-ilibrary.org/docserver/9789264220676-9en.pdf?expires $=1635846109 \& i d=i d \&$ accname $=$ guest $\&$ checksum $=F F 641$ A2BCB4F38C96D99F 29D8BA26788

Drukker, D. M. (2003). Testing for serial correlation in linear panel-data models. Stata Journal, 3(2), 168-177.

Farkas, G. (2005). Fixed- Effects Models. Encyclopedia of Social Measurement. https://doi.org/10.1016/B0-12-369398-5/00161-4

Freire-Seoane, M., Lopez-Bermudez, B., \& Zarzuelo, I. (2020). The effects of maritime container transport on economic growth in the countries on the west coast of Latin America. Revista CEPAL, Naciones Unidas Comisión Económica para América Latina y el Caribe (CEPAL), April. https://repositorio.cepal.org/bitstream/handle/11362/45977/1/RVI130_Freire.pdf

Gautam, S. (2020). Impact of Bridge Construction for Improved Livelihood in Rural Area. Nepalese Journal of Development and Rural Studies. 17. 112-122. 10.3126/njdrs.v17i0.35029.

Fulmer, J., (2009). What in the world is infrastructure? Retrieved from https://30kwe1si3or29z2y020bgbet-wpengine.netdna-ssl.com/wp-

content/uploads/2018/03/what-in-the-world-is-infrastructure.pdf

Gordon, E., Hays, J., Pollack, E., Sanchez, D., \& Walsh, J. (2011). Water Works: Rebuilding Infrastructure, Creating Jobs, Greening the Environment. Green For All. Retrieved from https://pacinst.org/wp-content/uploads/2013/02/water_works.pdf

Greene, W.H. (2002). Econometric Analysis. 5th Edition, Prentice Hall, Upper Saddle River, 802.

Gujarati, D., \& Porter, C. (2008). Basic Econometrics. 5th Edition, New York, NY: McGraw-Hill Education. 
Hair, J. F., Black, W. C., Babin, B. J., Anderson, R. E., \& Tatham, R. (2006). Multivariate data analysis. Upper Saddle River.

Etemadnia, H., Hassan, A., Goetz, S., \& Abdelghany, K. (2013). Wholesale Hub Locations in Food Supply Chains. Transportation Research Record, 2379(1), 80-89. https://doi.org/10.3141/237910

Henningsen, A., Henningsen, G., (2019). Analysis of panel data using R, panel data econometrics: theory. https://doi.org/10.1016/B978-0-12-814367-4.00012-5.

Hellin J., Lundy M., and Meijer M. (2009). Farmer organization, collective action and market access in Meso-America. Food Policy, Elsevier, 34(1), 16-22.

Holl, A. (2012). Market potential and firm-level productivity in Spain. Journal of Economic Geography, 12(6), 1191-1215.

Holl, A. (2016). Highways and productivity in manufacturing firms. Journal of Urban Economics. 93, 131-151.doi:10.1016/j.jue.2016.04.002

Hoechle, D. (2007). Robust standard errors for panel regressions with cross-sectional dependence. Stata Journal, 7(3), 281-312.

Hontley, J. (2021). Explainer: Economic Effects of Infrastructure Investment. Retrieved from https://budgetmodel.wharton.upenn.edu/issues/2021/6/15/economic-effects-of-infrastructureinvestment

Ibok, E., \& Daniel, E. (2013). The Impact of Rural Roads and Bridges on the Socio-economic Development of Akwa Ibom State, Nigeria: An Evaluation, 1, 27-36.

Jiménez, J. L., \& Perdiguero, J. (2011). Does Accessibility Affect Retail Prices and Competition? An Empirical Application., 11(4), 677-699. doi:10.1007/s11067-010-9144-5.

Miao, L., Gu, H., Zhang, X., Zhen, W., \& Wang, M. (2019). Factors causing regional differences in China's residential CO2 emissions-Evidence from provincial data. Journal of Cleaner Production, S0959652619309813-.doi:10.1016/j.jclepro.2019.03.271

Mitra, R. (2013). Leveraging Service Sector Growth in the Philippines. Retrieved from https://www.adb.org/sites/default/files/publication/30385/ewp-366.pdf

Moundigbaye, M., Messemer, C., Parks, R. W., \& Reed, W. R. (2019). Bootstrap methods for inference in the Parks model. Economics Discussion Papers No. 2019-39, Kiel Institute for the World Economy (IfW), Kiel. http://dx.doi.org/10.7910/DVN/94EU5T

Nayeripour M., \& Kheshti, M. (2011). Renewable Energy-Trends and Applications. 10.5772/1396.

Ng, C., Law, T., Jakarni, F., \& Kulanthayan, S. (2019). Road infrastructure development and economic growth. Retrieved from https://iopscience.iop.org/article/10.1088/1757$899 X / 512 / 1 / 012045 / \mathrm{pdf}$

Nilsson, I., \& Smirnov, O. (2016). Measuring the effect of transportation infrastructure on retail firm co-location patterns. Journal of Transport Geography, 51, 110118.doi:10.1016/j.jtrangeo.2015.12.002

Ocampo, K. (2018). To Realize Duterte's 'Golden Age of Infrastructure' in Philippines, Better Roads a Must. Retrieved from https://asiafoundation.org/2018/01/31/realize-dutertes-golden-ageinfrastructure-philippines-better-roads-must/

Okello J., Narrod C., and Roy D. (2007). Food Safety Requirements in African Green Bean Exports and Their Impact on Small Farmers. International Food Policy Research Institute

O'Sullivan, A., \& Sheffrin, S. M. (2003). Economics: Principles in Action. Upper Saddle River, NJ: Pearson Prentice Hall.

Pallant, J. (2007). SPSS survival manual-A step by step guide to data analysis using SPSS for windows (3rd ed.). Maidenhead: Open University Press.

Perry, D. C. (2001). Infrastructure investment. International Encyclopedia of the Social \& Behavioral Sciences, 7486-7489. https://doi.org/10.1016/b0-08-043076-7/04411-9

Pesaran, M. H. (2004). General diagnostic tests for cross-section dependence in panels, CESifo Working Paper, No. 1229, Center for Economic Studies and Ifo Institute (CESifo), Munich

Pradhan, R., \& Bagchi, T. (2013). Effect of transportation infrastructure on economic growth in India: The VECM approach. Research in Transportation Economics, 38(1), 139-148. doi:10.1016/j.retrec.2012.05.008

Philippine Statistics Authority. (2016). Industry and Services Sector Tops Performance. Retrieved from https://psa.gov.ph/content/industry-and-services-sector-tops-performance

Reed, W. R., \& Webb, R. (2010). The PCSE estimator is good--just not as good as you think. 
Retrieved content/uploads/2011/08/Reed_The_PCSE_Estimator_is_Good.pdf

https://www.nzae.org.nz/wp-

Reed, W. R., \& Ye, H. (2009). Which panel data estimator should I use?, Applied Economics, 43(8), 985-1000.

Sabir, S., \& Shamshir, M. (2020). Impact of economic and social infrastructure on the long-run economic growth of Pakistan. Sustainable Water Resources Management, 6. 10.1007/s40899020-00361-3.

Siyan, P., Makwe, E., \& Rita, E. (2015). The Impact of Road Transportation Infrastructure on Economic Growth in Nigeria. 3(1), 673-680.

Slamet, A., Nakayasu, A., \& Ichikawa, M. (2017). Small-Scale Vegetable Farmers' Participation in Modern Retail Market Channels in Indonesia: The Determinants of and Effects on Their Income. Retrieved from https://www.mdpi.com/2077-0472/7/2/11/htm

StataCorp. (2013). Stata Glossary and Index: Release 13. Retrieved from https://www.stata.com/manuals13/i.pdf\#iiIndex

Stupak, J. (2018). Economic Impact of Infrastructure Investment. Retrieved from https://sgp.fas.org/crs/misc/R44896.pdf

Sullivan, M. (2016). Retail Versus Wholesale Business Models: What's Best For My Business?. Retrieved from https://quickbooks.intuit.com/global/resources/starting-up/retail-versuswholesale-business-models-whats-best-for-my-business/

Torres-Reyna, O. (2007). Panel Data Analysis Fixed* Random Effects Using Stata 10.x (v.er 4.1). Data \& Statistical Services, Princeton University. Retrieved from https://www.princeton.edu/ otorres/Panel101.pdf

Tugcu, C. T. (2018). The Economics and Econometrics of the Energy-Growth Nexus || Panel Data Analysis in the Energy-Growth Nexus (EGN)., (), 255-271.doi:10.1016/B978-0-12-8127469.00008-0

Verbeek, M. (2004). A Guide to Modern Econometrics, 2. ed., Chichester: John Wiley \& Sons.

Wooldridge, J. M. (2002). Econometric Analysis of Cross Section and Panel Data.

World Bank. (1994). Infrastructure: Achievements, Challenges, and Opportunities. Retrieved from https://openknowledge.worldbank.org/bitstream/handle/10986/5977/9780195209921_ch01.pdf

Yu, N., De Jong, M., Storm, S., \& Mi, J. (2012). The growth impact of transport infrastructure investment: A regional analysis for China (1978-2008), 31(1), 038.doi:10.1016/j.polsoc.2012.01.004 